\title{
Design A Lighting Point Calculator System For Residential Houses Using Microsoft Visual Basic
}

\author{
Fatin Farhah Nazaruddin ${ }^{1}$, Nur Hanis Mohammad Radzi ${ }^{1 *}$ \\ ${ }^{1}$ Faculty of Electrical and Electronic Engineering, \\ Universiti Tun Hussein Onn Malaysia, 86400, Parit Raja, MALAYSIA \\ *Corresponding Author
}

DOI: https://doi.org/10.30880/jeva.2021.02.02.008

Received 18 July 2021; Accepted 09 December 2021; Available online 30 December 2021

\begin{abstract}
Lighting point calculation plays an important feature in developing a new residential house. This enables people inside the house will have enough of light to perform tasks efficiently. Currently, consulting electrical engineers use rules of thumb to forecast the quantity of lighting points, however these rules are inaccurate. It does not take into account the lux required based on Malaysian Standard MS1525. Furthermore, good lighting can save money and provide visual comfort to the occupants. However, numerous parameters such as room index, utilisation factor and illuminance used for each space or room inside the house must be considered when determining the quantity of lighting point for a residential property. Three types of residential houses are considered which are: single storey house, double storey house and condominium house. This paper presents the development of lighting point calculator system for residential houses using Microsoft Visual Basic and comparison of quantity of lighting point using manual calculation using Microsoft Excel and simulation calculation using Microsoft Visual Basic.
\end{abstract}

Keywords: Lighting point calculation, residential houses, microsoft excel, microsoft visual basic

\section{Introduction}

As the world transforms into a highly industrialized and modern era, the evolvement on the lighting calculation of residential houses have to be appreciated. The lighting calculation from manual estimation using Rule's of Thumb, now have been made some improvement that makes the consultant engineer work easier. Focusing on the lighting, it is one of the most important elements in providing good interior design of a residence. This allows people to perform visual tasks efficiently and accurately [1]. Bad lighting will lead many problems such as insufficient light, glare, improper contrast, poor distributed light and flicker [2]. There are many factors contribute to bad lighting, so an appropriate design of quantity of lighting point should precisely calculate in order to not short designed or over designed the quantity while ensuring quality and quantity of illumination in the house.

However, lighting calculation requires many factors related with it. The area of the room, the type of lamp used and the function of the room plays a crucial factor in order to give the proper amount lighting point in the room. This factor is closely related to the lumen method. It also called Photometrical Computation and widely used for interior lighting calculation [3]. In addition, these factors determine the preciseness of the output result. In developing a new system, it is important to have a guideline or standard, while doing this to ensure the reliability of the result. Therefore, Malaysian Standard, MS 1525 is a standard that this project referring to. To sum up, the quality of the lighting ensures coziness of the house as the resident's comfort and satisfaction are always be a priority of a consultant electrical engineer. 


\section{Methodology}

This section describes the flowchart of the project, type of lamp used and the procedures in determining the quantity of lighting points for each room or space in the house.

\subsection{Flowchart Of The Project}

This project achievement method was divided into several stages to make the flow of the project more systematic and manageable. Figure 1 shows the flowchart of the project from the beginning until the end of the project. This flowchart is used to guide the process of Microsoft Excel calculation for determining the quantity of lighting point up to designing a calculator system using Microsoft Visual Basic and make a comparison between two calculation methods.

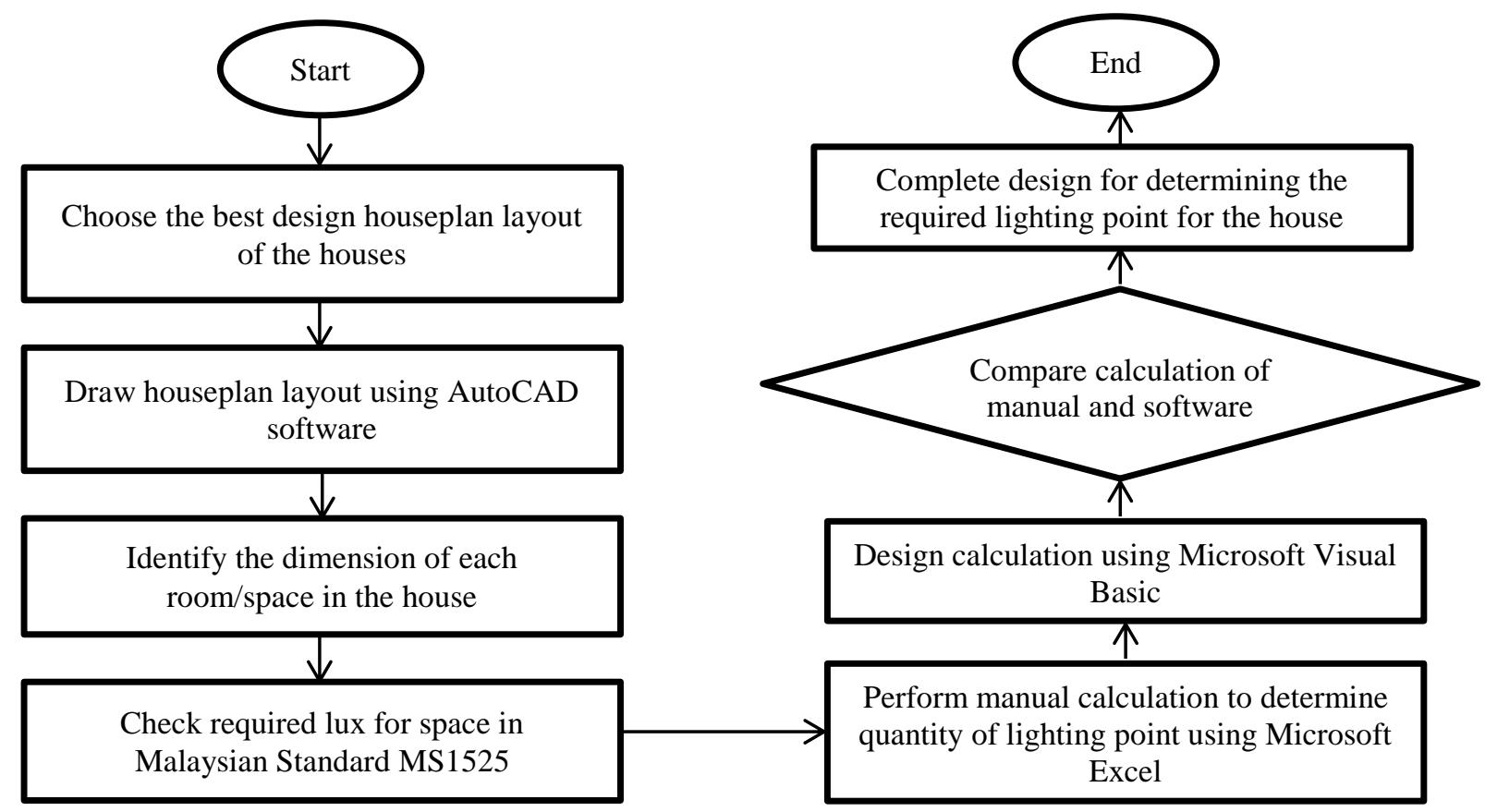

Fig. 1 - Flowchart of overall project

\subsection{Type of Lamp Used}

Figure 2 shows the type of lamp used which is PHILIPS 50W LED TRUEFORCE E27 5000 lumen. This lamp is chosen because it is one of the best lightning as it is known as energy saving lamp. By using using this type of lamp, it can save the budget for electricity bill in the future while having sufficient brightness of the lamp. In this new era technology, lumen knowledge has been wider spread as lumens of the lamp are more accurate when determining the brightness of the lamp especially when it related to LEDs [6]. Besides that, the cost for 1 lamp for this type of lamp is only below RM50. Although this quite expensive but good element from this lamp worth it as it has longer lifespan and energy saving.

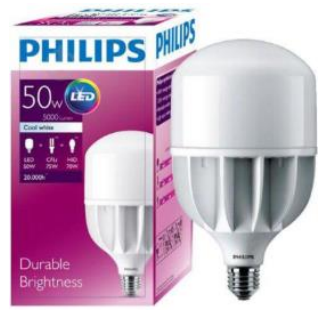

Fig. 2 - PHILIPS 50W LED TRUEFORCE E27 5000 lumen

\subsection{Procedures in Determining Quantity of Lighting Points}

The method used to determine the quantity of lighting point is lumen method. Step by step calculation were shown in Figure 3 and these only applicable for one room or space only, so this steps will be repeated according to the number of room to be calculated. While Figure 4 and Figure 5 shows the recommended average illuminance level based on Malaysian Standard, MS 1525:2007 and the utilisation factor table respectively. The average illuminance (lux) value used when determining illuminance (lux) required for the room or space later. 


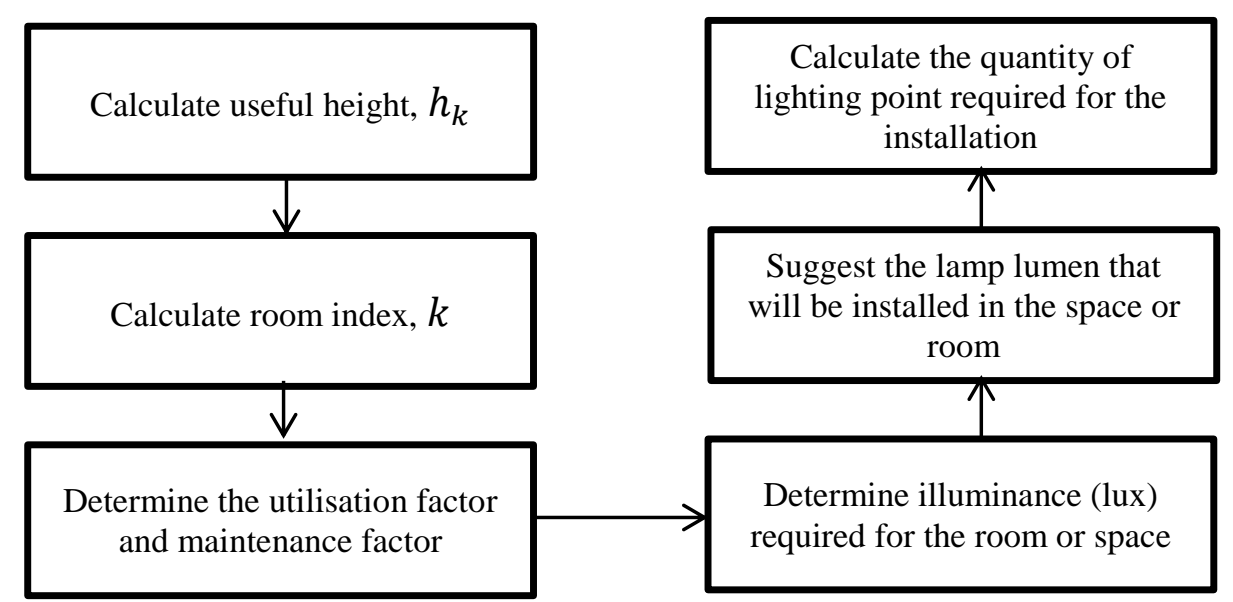

Fig. 3 - Step by step calculation to determine quantity of lighting point for one room or space only

\begin{tabular}{|c|c|c|}
\hline Task & $\begin{array}{c}\text { Illuminance } \\
\text { (lux) }\end{array}$ & Example of Applications \\
\hline $\begin{array}{l}\text { Lighting for } \\
\text { infrequently used } \\
\text { area }\end{array}$ & $\begin{array}{l}20 \\
100 \\
100 \\
100 \\
100 \\
150 \\
100 \\
100 \\
100 \\
100 \\
300 \\
200\end{array}$ & $\begin{array}{l}\text { Minimum service } \\
\text { Interior walkway and carpark } \\
\text { Hotel bedroom } \\
\text { Lift Interior } \\
\text { Corridor, passageways, stairs } \\
\text { Escalator, travellator } \\
\text { Entrance and exit } \\
\text { Staff changing room, locker and cleaner } \\
\text { room, lavatories, stores } \\
\text { Entrance hall, lobbies, waiting room } \\
\text { Inquiry desk } \\
\text { Gate house }\end{array}$ \\
\hline $\begin{array}{l}\text { Lighting for } \\
\text { working area }\end{array}$ & $\begin{array}{c}200 \\
300-400 \\
\\
300-400 \\
150 \\
200 \\
150-300 \\
150 \\
150 \\
100 \\
100 \\
300-500 \\
200-750 \\
300 \\
\end{array}$ & $\begin{array}{l}\text { Infrequent reading and writing } \\
\text { General offices, shops and stores, reading } \\
\text { and writing } \\
\text { Drawing office } \\
\text { Restroom } \\
\text { Rertaurant, canteen, cafeteria } \\
\text { Kitchen } \\
\text { Lounge } \\
\text { Bathroom } \\
\text { Toilet } \\
\text { Bedroom } \\
\text { Classroom, library } \\
\text { Shop/Supermarket/Department store } \\
\text { Museum and gallery }\end{array}$ \\
\hline $\begin{array}{l}\text { Localised lighting } \\
\text { for exacting task }\end{array}$ & $\begin{array}{c}500 \\
1000 \\
2000\end{array}$ & $\begin{array}{l}\text { Proof reading } \\
\text { Exacting drawing } \\
\text { Detailed and precise work }\end{array}$ \\
\hline
\end{tabular}

Fig. 4 - Recommended average illuminance level based on Standards Malaysia 2007

\begin{tabular}{|c|c|c|c|c|c|c|c|c|c|c|c|}
\hline \multicolumn{6}{|c|}{ Room Reflection } & \multicolumn{6}{|c|}{ Room Index } \\
\hline C & w & $\mathrm{F}$ & .75 & 1.00 & 1.25 & 1.50 & 2.00 & 2.50 & 3.00 & 4.00 & 5.00 \\
\hline \multirow[t]{3}{*}{70} & .50 & 20 & -44 & 50 & .56 & 60 & .65 & 69 & .72 & .75 & 77 \\
\hline & .30 & & -38 & .44 & .50 & .54 & .60 & .64 & .68 & .72 & .74 \\
\hline & .10 & & -33 & -40 & .46 & .50 & .56 & .61 & .64 & .69 & .72 \\
\hline \multirow[t]{3}{*}{50} & 50 & 200 & 39 & 4 & 49 & -52 & .57 & .600 & 62 & .65 & 67 \\
\hline & 30 & & .34 & -40 & .44 & -48 & .53 & .56 & .59 & .62 & .64 \\
\hline & .10 & & 30 & 36 & .41 & .44 & .50 & .53 & .56 & .60 & .62 \\
\hline \multirow[t]{3}{*}{30} & .50 & 20 & 34 & 39 & 42 & -45 & 49 & .51 & 53 & .55 & .57 \\
\hline & 30 & & 30 & .35 & .39 & .42 & .46 & .49 & .51 & .53 & .55 \\
\hline & 10 & & .27 & 32 & 36 & 39 & .44 & .47 & .49 & .52 & .54 \\
\hline ōò & "ōō" & öö & 22 & 26 & 29 & 31 & 34 & 36 & 38 & 40 & 41 \\
\hline
\end{tabular}

Fig. 5 - Utilisation factor table 


\subsection{Formulae And Equations Related}

The formula and equations related to determine quantity of lighting point are calculated according to multiple terms which are Room Index, Useful Height, Utilisation Factor, Maintenance Factor and Quantity of Lighting Point [3][4][5].

i. $\quad$ Room Index, $k$

$$
k=\frac{l+w}{h_{k}(l+w)}
$$

$$
\begin{array}{ll}
\text { where; } & k=\text { Room Index } \\
& l=\text { Length of room/space (in meter) } \\
w & =\text { Width of room/space (in meter) } \\
& h_{k}=\text { Useful height (in meter) }
\end{array}
$$

i i. Useful Height, $h_{k}$

$$
\begin{aligned}
& h_{k}=h-h_{d} \\
& \text { where; } \quad h_{k}=\text { Useful height (in meter) } \\
& h=\text { Height from floor to ceiling (in meter) } \\
& h_{d}=\text { Height of working area (in meter) }
\end{aligned}
$$

iii. Utilisation Factor [7]

For the value less than 0.75 , utilisation factor will be normalized to 0.75 . For example, Room Index $=0.68$;

$$
U F=\frac{0.44[\text { from_UtilisationFactor_RI }(0.75)] \times 0.68}{0.75}
$$

For the value greater than 0.75 , utilisation factor will be read directly from the table and if the value in between two Room Index value, the higher value will be selected. For example, Room Index $=0.84$;

$$
U F=0.5[\text { from_UtilisationFactorTable_RI(1.00)] }
$$

iv. Maintenance Factor

For the residential house, the Maintenance Factor was fixed to 0.85 .

v. Quantity of lighting point, $N$

$$
N=\frac{E \times A}{\phi \times U F \times M F}
$$

where; $\quad N=$ Quantity of lighting point

$E=$ Illuminance required for the room/space (in lux)

$A=$ Area of the room (in meter square)

$\emptyset=$ Lumen of the lamp (in lumen)

$U F \& M F=$ Utilisation factor and maintenance factor respectively 


\section{Result and Discussion}

\subsection{Layout Of Residential Houses}

There are three case studies were carried out which are single storey house, double storey house and condominium house. These three types of house are designed according to the sample of common design of residential houses. The layout of the residential houses was designed and illustrated using AutoCAD software 2018 version. Figure 6 shows all the three layout of the residential houses.

(a)

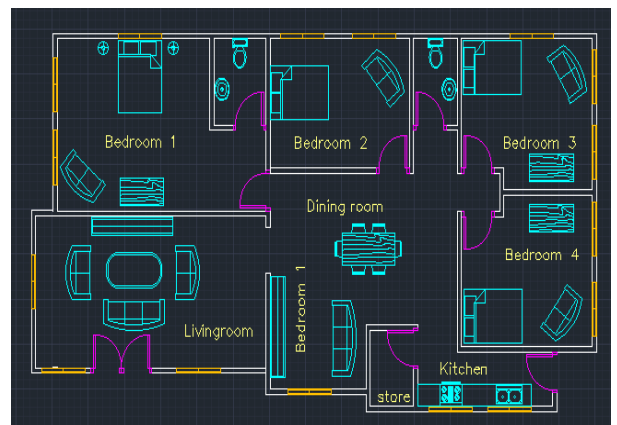

(c)

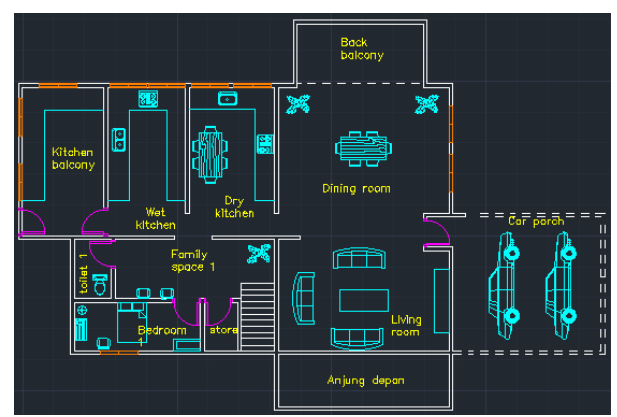

(b)

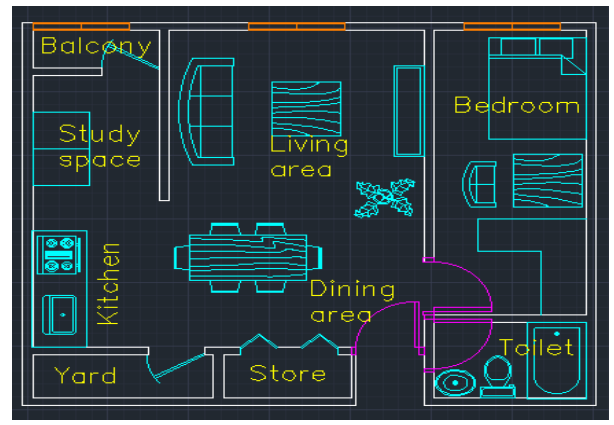

(d)

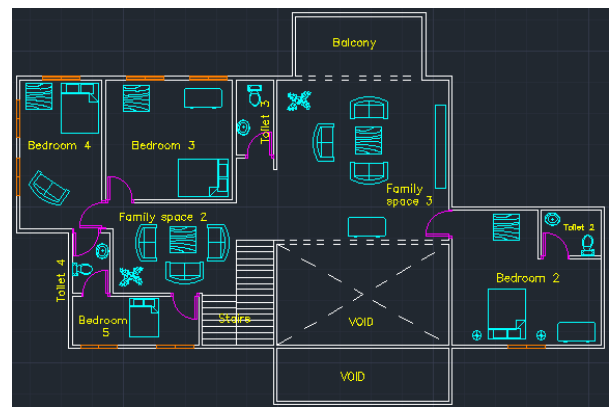

Fig. 6 - (a) Layout of single storey house; (b) Layout of condominium house; (c) Layout of ground floor of double storey house; (d) Layout of first floor of double storey house

\subsection{Information of Residential Houses}

Table 1 - Table 3 shows the details of each room or space inside the house which are the dimension and room index of the room or space that will be useful to calculate the quantity of lighting point for the residential house.

Table 1 - Details of each room or space inside single storey house

\begin{tabular}{lcccc}
\hline $\begin{array}{l}\text { Type of room / } \\
\text { space }\end{array}$ & $\begin{array}{c}\text { Length } \\
(\boldsymbol{m})\end{array}$ & $\begin{array}{c}\text { Width } \\
(\boldsymbol{m})\end{array}$ & $\begin{array}{c}\text { Useful } \\
\text { height } \\
(\boldsymbol{m})\end{array}$ & Room Index \\
\hline Living room & 7.8 & 4.7 & 2.25 & 1.29 \\
Bedroom 1 & 7.2 & 4.1 & 2.25 & 1.15 \\
Bedroom 2 & 4.8 & 3.6 & 2.25 & 0.91 \\
Bedroom 3 & 4.5 & 3.6 & 2.25 & 0.89 \\
Bedroom 4 & 4.5 & 3.6 & 2.25 & 0.89 \\
Toilet 1 & 1.8 & 2.4 & 2.25 & 0.46 \\
Toilet 2 & 1.5 & 2.4 & 2.25 & 0.41 \\
Family space & 6.3 & 3.6 & 2.25 & 1.02 \\
Store & 1.5 & 2.1 & 2.25 & 0.39 \\
Kitchen & 4.5 & 1.8 & 2.25 & 0.57 \\
Balcony1 & 5.4 & 1.5 & 2.25 & 0.52 \\
Balcony 2 & 2.4 & 2.4 & 2.25 & 0.53 \\
Balcony 3 & 1.2 & 1.8 & 2.25 & 0.32 \\
\hline
\end{tabular}


Table 2 - Details of each room or space inside condominium house

\begin{tabular}{lcccc}
\hline $\begin{array}{l}\text { Type of room / } \\
\text { space }\end{array}$ & $\begin{array}{c}\text { Length } \\
(\boldsymbol{m})\end{array}$ & $\begin{array}{c}\text { Width } \\
(\boldsymbol{m})\end{array}$ & $\begin{array}{c}\text { Useful } \\
\text { height } \\
(\boldsymbol{m})\end{array}$ & Room Index \\
\hline Balcony & 1.9 & 0.7 & 2.25 & 0.24 \\
Study space & 1.9 & 2.5 & 2.25 & 0.49 \\
Kitchen & 1.9 & 2.9 & 2.25 & 0.52 \\
Yard & 2.9 & 0.9 & 2.25 & 0.33 \\
Living area & 3.9 & 3.2 & 2.25 & 0.78 \\
Dining area & 3.9 & 2.9 & 2.25 & 0.74 \\
Store & 1.9 & 1.0 & 2.25 & 0.29 \\
Bedroom & 2.4 & 5.6 & 2.25 & 0.74 \\
Toilet & 2.4 & 1.5 & 2.25 & 0.40 \\
\hline
\end{tabular}

Table 3 - Details of each room or space inside double storey house

\begin{tabular}{|c|c|c|c|c|}
\hline $\begin{array}{l}\text { Type of room / } \\
\text { space }\end{array}$ & $\begin{array}{l}\text { Length } \\
\text { (m) }\end{array}$ & $\begin{array}{l}\text { Width } \\
(m)\end{array}$ & $\begin{array}{c}\text { Useful } \\
\text { height } \\
(m)\end{array}$ & Room Index \\
\hline Bedroom 1 & 5.1 & 1.8 & 2.25 & 0.59 \\
\hline Toilet 1 & 1.5 & 2.4 & 2.25 & 0.41 \\
\hline Family space 1 & 6.3 & 2.4 & 2.25 & 0.77 \\
\hline Store room & 1.2 & 1.8 & 2.25 & 0.32 \\
\hline Living room & 6.9 & 3.9 & 2.25 & 1.11 \\
\hline Balcony 1 & 6.9 & 5.1 & 2.25 & 1.30 \\
\hline Kitchen balcony & 3.3 & 6.0 & 2.25 & 0.95 \\
\hline Dry kitchen & 3.0 & 6.0 & 2.25 & 0.89 \\
\hline Wet kitchen & 3.3 & 6.0 & 2.25 & 0.95 \\
\hline Dining room & 6.9 & 2.1 & 2.25 & 0.72 \\
\hline Back balcony & 5.1 & 2.4 & 2.25 & 0.73 \\
\hline Car porch & 6.0 & 5.4 & 2.25 & 1.26 \\
\hline Stairs & 1.2 & 2.7 & 2.25 & 0.37 \\
\hline Bedroom 2 & 6.0 & 5.4 & 2.25 & 1.26 \\
\hline Toilet 2 & 2.4 & 1.8 & 2.25 & 0.46 \\
\hline Bedroom 3 & 5.1 & 4.8 & 2.25 & 1.10 \\
\hline Bedroom 4 & 3.3 & 6.0 & 2.25 & 0.95 \\
\hline Bedroom 5 & 5.1 & 1.8 & 2.25 & 0.59 \\
\hline Toilet 3 & 1.5 & 3.0 & 2.25 & 0.44 \\
\hline Family space 2 & 6.3 & 3.6 & 2.25 & 1.02 \\
\hline Family space 3 & 6.9 & 5.1 & 2.25 & 1.30 \\
\hline Toilet 4 & 1.5 & 2.4 & 2.25 & 0.41 \\
\hline Stairs & 2.7 & 4.2 & 2.25 & 0.73 \\
\hline Upper balcony & 5.1 & 2.4 & 2.25 & 0.73 \\
\hline
\end{tabular}

\subsection{Lighting Point Calculator Using Microsoft Visual Basic}

After the application is designed, the user can calculate the quantity of lighting point by inserting value of length, width, height, illuminance (lux) used and lumen of the lamp. Figure 7 shows the interface of the lighting point calculator application system using Microsoft Visual Basic. 


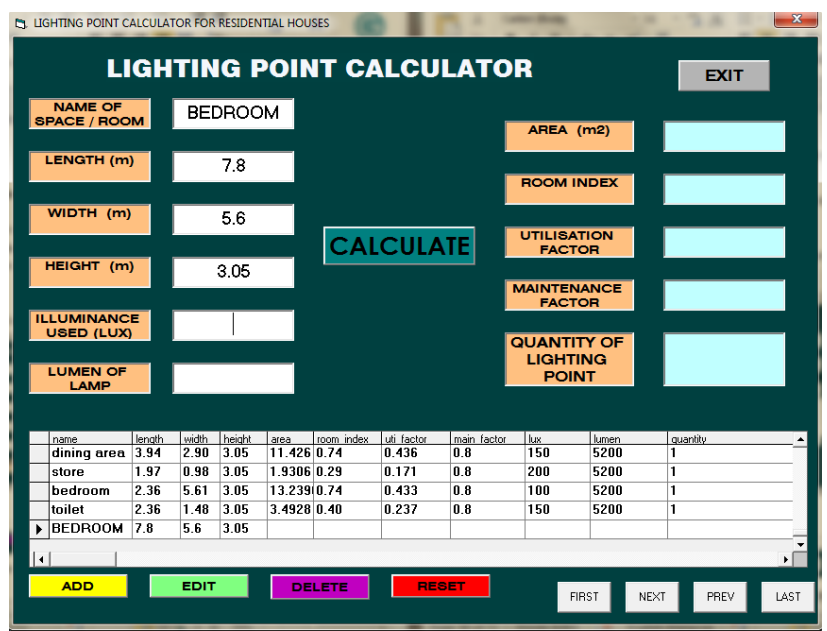

Fig. 7 - User interface of lighting point calculator application system using Microsoft Visual Basic

\subsection{Comparison Of Results Between Manual Calculation and Simulation Calculation}

The comparison of results between manual calculation and simulation calculation was illustrated in Table 4 - Table 6. This comparison will determine the reliability of the result from the simulation calculation from Microsoft Visual Basic.

Table 4 - Results comparison between Microsoft Excel and Microsoft Visual Basic simulation of each room or space inside single storey house

\begin{tabular}{|c|c|c|c|c|c|c|c|}
\hline \multirow{2}{*}{$\begin{array}{l}\text { Type of } \\
\text { room / } \\
\text { space }\end{array}$} & \multicolumn{3}{|c|}{ Excel calculation } & \multicolumn{3}{|c|}{ Visual Basic simulation calculation } & \multirow{2}{*}{$\begin{array}{c}\text { Differences of } \\
\text { utilisation factor } \\
(\%)\end{array}$} \\
\hline & $\begin{array}{l}\text { Room } \\
\text { index }\end{array}$ & $\begin{array}{l}\text { Utilisation } \\
\text { factor }\end{array}$ & $\begin{array}{l}\text { Quantity } \\
\text { of lighting } \\
\text { point }\end{array}$ & $\begin{array}{l}\text { Room } \\
\text { index }\end{array}$ & $\begin{array}{l}\text { Utilisation } \\
\text { factor }\end{array}$ & $\begin{array}{l}\text { Quantity } \\
\text { of lighting } \\
\text { point }\end{array}$ & \\
\hline Living room & 1.29 & 0.516 & 3 & 1.29 & 0.518 & 3 & 0.38 \\
\hline Bedroom 1 & 1.15 & 0.515 & 1 & 1.15 & 0.516 & 1 & 0.19 \\
\hline Bedroom 2 & 0.91 & 0.455 & 1 & 0.91 & 0.457 & 1 & 0.43 \\
\hline Bedroom 3 & 0.89 & 0.445 & 1 & 0.89 & 0.444 & 1 & 0.22 \\
\hline Bedroom 4 & 0.89 & 0.445 & 1 & 0.89 & 0.444 & 1 & 0.22 \\
\hline Toilet 1 & 0.46 & 0.270 & 1 & 0.46 & 0.268 & 1 & 0.74 \\
\hline Toilet 2 & 0.41 & 0.241 & 1 & 0.41 & 0.241 & 1 & 0.00 \\
\hline Family space & 1.02 & 0.457 & 2 & 1.02 & 0.456 & 2 & 0.22 \\
\hline \multicolumn{8}{|l|}{ Store } \\
\hline Kitchen & 0.39 & 0.229 & 1 & 0.39 & 0.228 & 1 & 0.43 \\
\hline Balcony 1 & 0.57 & 0.334 & 2 & 0.57 & 0.335 & 2 & 0.29 \\
\hline Balcony 2 & 0.52 & 0.305 & 1 & 0.52 & 0.306 & 1 & 0.33 \\
\hline \multirow[t]{2}{*}{ Balcony 3} & 0.53 & 0.311 & 1 & 0.53 & 0.313 & 1 & 0.63 \\
\hline & 0.32 & 0.188 & 1 & 0.32 & 0.188 & 1 & 0.00 \\
\hline
\end{tabular}


Table 5 - Results comparison between Microsoft Excel and Microsoft Visual Basic simulation of each room or space inside condominium house

\begin{tabular}{|c|c|c|c|c|c|c|c|}
\hline \multirow{2}{*}{$\begin{array}{l}\text { Type of } \\
\text { room / } \\
\text { space }\end{array}$} & \multicolumn{3}{|c|}{ Excel calculation } & \multicolumn{3}{|c|}{ Visual Basic simulation calculation } & \multirow{2}{*}{$\begin{array}{c}\text { Differences of } \\
\text { utilisation factor } \\
(\%)\end{array}$} \\
\hline & $\begin{array}{l}\text { Room } \\
\text { index }\end{array}$ & $\begin{array}{l}\text { Utilisation } \\
\text { factor }\end{array}$ & $\begin{array}{c}\text { Quantity } \\
\text { of lighting } \\
\text { point }\end{array}$ & $\begin{array}{l}\text { Room } \\
\text { index }\end{array}$ & $\begin{array}{l}\text { Utilisation } \\
\text { factor }\end{array}$ & $\begin{array}{l}\text { Quantity } \\
\text { of lighting } \\
\text { point }\end{array}$ & \\
\hline Balcony & 0.24 & 0.141 & 1 & 0.24 & 0.140 & 1 & 0.71 \\
\hline Study space & 0.49 & 0.288 & 1 & 0.49 & 0.285 & 1 & 1.05 \\
\hline Kitchen & 0.52 & 0.305 & 1 & 0.52 & 0.306 & 1 & 0.33 \\
\hline Yard & 0.33 & 0.194 & 1 & 0.33 & 0.192 & 1 & 1.04 \\
\hline Living area & 0.78 & 0.390 & 2 & 0.78 & 0.392 & 2 & 0.51 \\
\hline Dining area & 0.74 & 0.434 & 1 & 0.74 & 0.436 & 1 & 0.46 \\
\hline Store & 0.29 & 0.170 & 1 & 0.29 & 0.171 & 1 & 0.59 \\
\hline Bedroom & 0.74 & 0.434 & 1 & 0.74 & 0.433 & 1 & 0.23 \\
\hline Toilet & 0.40 & 0.235 & 1 & 0.40 & 0.237 & 1 & 0.85 \\
\hline
\end{tabular}

Table 6 - Results comparison between Microsoft Excel and Microsoft Visual Basic simulation of each room or space inside double storey house

\begin{tabular}{|c|c|c|c|c|c|c|c|}
\hline \multirow[b]{2}{*}{$\begin{array}{c}\text { Type of room / } \\
\text { space }\end{array}$} & \multicolumn{3}{|c|}{ Excel calculation } & \multicolumn{3}{|c|}{ Visual Basic simulation calculation } & \multirow{2}{*}{$\begin{array}{l}\text { Differences of } \\
\text { utilisation factor } \\
(\%)\end{array}$} \\
\hline & $\begin{array}{l}\text { Room } \\
\text { index }\end{array}$ & $\begin{array}{l}\text { Utilisation } \\
\text { factor }\end{array}$ & $\begin{array}{c}\text { Quantity } \\
\text { of lighting } \\
\text { point }\end{array}$ & $\begin{array}{l}\text { Room } \\
\text { index }\end{array}$ & $\begin{array}{l}\text { Utilisation } \\
\text { factor }\end{array}$ & $\begin{array}{l}\text { Quantity } \\
\text { of lighting } \\
\text { point }\end{array}$ & \\
\hline Bedroom 1 & 0.59 & 0.346 & 1 & 0.59 & 0.347 & 1 & 0.28 \\
\hline Toilet 1 & 0.41 & 0.241 & 1 & 0.41 & 0.241 & 1 & 0.00 \\
\hline Family space 1 & 0.77 & 0.385 & 2 & 0.77 & 0.386 & 2 & 0.26 \\
\hline Store room & 0.32 & 0.188 & 1 & 0.32 & 0.188 & 1 & 0.00 \\
\hline Living room & 1.11 & 0.497 & 3 & 1.11 & 0.496 & 3 & 0.20 \\
\hline Balcony 1 & 1.30 & 0.520 & 3 & 1.30 & 0.521 & 3 & 0.19 \\
\hline Kitchen balcony & 0.95 & 0.475 & 2 & 0.95 & 0.473 & 2 & 0.42 \\
\hline Dry kitchen & 0.89 & 0.445 & 3 & 0.89 & 0.444 & 3 & 0.23 \\
\hline Wet kitchen & 0.95 & 0.475 & 3 & 0.95 & 0.473 & 3 & 0.42 \\
\hline Dining room & 0.72 & 0.422 & 2 & 0.72 & 0.420 & 2 & 0.48 \\
\hline Back balcony & 0.73 & 0.428 & 1 & 0.73 & 0.426 & 1 & 0.47 \\
\hline Car porch & 1.26 & 0.504 & 2 & 1.26 & 0.505 & 2 & 0.20 \\
\hline Stairs & 0.37 & 0.217 & 1 & 0.37 & 0.217 & 1 & 0.00 \\
\hline Bedroom 2 & 1.26 & 0.504 & 2 & 1.26 & 0.505 & 2 & 0.20 \\
\hline Toilet 2 & 0.46 & 0.270 & 1 & 0.46 & 0.268 & 1 & 0.75 \\
\hline Bedroom 3 & 1.10 & 0.493 & 1 & 1.10 & 0.492 & 1 & 0.20 \\
\hline Bedroom 4 & 0.95 & 0.475 & 1 & 0.95 & 0.473 & 1 & 0.42 \\
\hline Bedroom 5 & 0.59 & 0.346 & 1 & 0.59 & 0.347 & 1 & 0.29 \\
\hline Toilet 3 & 0.44 & 0.258 & 1 & 0.44 & 0.261 & 1 & 1.16 \\
\hline Family space 2 & 1.02 & 0.457 & 2 & 1.02 & 0.456 & 2 & 0.22 \\
\hline Family space 3 & 1.30 & 0.520 & 3 & 1.30 & 0.521 & 3 & 0.19 \\
\hline Toilet 4 & 0.41 & 0.241 & 1 & 0.41 & 0.241 & 1 & 0.00 \\
\hline Stairs & 0.73 & 0.428 & 1 & 0.73 & 0.429 & 1 & 0.23 \\
\hline Upper balcony & 0.73 & 0.428 & 1 & 0.73 & 0.426 & 1 & 0.47 \\
\hline
\end{tabular}

From all three cases study, there are slightly differences on the value of utilisation factor. The results from Microsoft Visual Basic application show differences of utilisation factor up to 1.16\% higher than the Microsoft Excel calculation. This is due to the decimal points taken by the previous calculation which is room index value were calculated from the length, width and height of the room or space. However, the quantity of lighting point for all three cases study is not affected. 


\section{Conclusion}

In conclusion, the lighting point calculation for residential houses has been performed using Microsoft Excel and Microsoft Visual Basic. In addition, the lighting point calculator application for residential houses also has been designed using Microsoft Visual Basic as well as the comparison of results between manual calculation and Microsoft Visual Basic simulation lighting point calculator application has been analyzed and investigated. The detailed formulae and equations determine the quantity lighting point, the procedure to use lighting point calculator application and the Malaysian Standard also has been clearly explained. The lighting point calculator application for residential houses is designed to estimate the quantity of lighting point for each space or room in a house. Research has been made to get the precise formula for the calculator. The user required to insert the value of length, width, height, illuminance used (lux) and lumen of the lamp used. The quantity of lighting point is calculated in MVB. From the result, it can be concluded that this proposed application suitable for consultant electrical engineer in determining the lighting point calculation for any type of residential houses with dimension insert in meter unit.

\section{Acknowledgement}

The authors would also like to extend deepest gratitude to the Faculty of Electrical and Electronic Engineering, Universiti Tun Hussein Onn Malaysia for the technical and continuous moral support.

\section{References}

[1] Standards Policy and Strategy, C. (2011). Light and Lighting - lighting of work places. BSI

[2] Chawre, A. (2019). Effects of Poor Lighting at Workplace [Online]. Available: https://www.ppsthane.com/blog/effects-of-poor-lighting-at-workplace. [Accessed March 25, 2021]

[3] Malaysia Standard MS1525, Energy efficiency and use of renewable energy for non-residential buildings - Code of practice, 2007

[4] Kralikova, R., Piňosová, M., \& Hricová, B., "Lighting Quality and Its Effects on Productivity and Human Health" (2016)

[5] IESNA, IES Lighting Handbook Reference and Application. New York: Illuminating Engineering Society of North America (IESNA), 2000

[6] Services, U. N. I. E. (2015, March 3). Comparing Lumens and Watts by LEDified. Ledified. http://www.ledified.com.au/the-difference-between-lumens-vs-watts-with-led-bulbs-2/.

[7] Alzuhairi, M. (n.d.). Lighting design and calculations [Web log post]. Retrieved 2020, from https://www.philadelphia.edu.jo/academics/mlazim/uploads/EI\%20Lecture\%20No.11.pdf 